\title{
INFLUENCE OF HEAT TREATMENT METHODS ON BIOACTIVE COMPOUND CONCENTRATIONS IN PUMPKIN - GUELDER ROSE (VIBURNUM OPULUS) SAUCES
}

\author{
Liene Ozola\# and Solvita Kampuse \\ Faculty of Food Technology, Latvia University of Life Sciences and Technologies, Jelgava, LV-3004, LATVIA \\ \# Corresponding author, lieneozola8@inbox.Iv
}

Communicated by Daina Kārkliṇa

\begin{abstract}
The objective of this study was to examine the suitability of heat treatment methods on concentrations of bioactive compounds in pumpkin-guelder rose sauce. Berry hybrids 2--30--K, 2--45--K and variety 'Krasnaya Grozdj' were selected for further research. The juice of these fruits was used to create pumpkin-guelder rose sauce samples (experimental samples) where the pumpkin puree and guelder rose fruit juice ratio was $74.5: 13.1$. To all samples heat treatment under atmospheric conditions (traditional cooking) and vacuum cooking at 0.6 bar pressure at $85{ }^{\circ} \mathrm{C}$ and 0.2 bar pressure at $75{ }^{\circ} \mathrm{C}$ temperature was performed. These samples were compared with uncooked experimental samples. Sauce chemical evaluation showed better retention of vitamin $C$ concentrations (per dry weight) for guelder rose variety 'Krasnaya Grozdj' sauces cooked at 0.2 bar pressure, compared to fresh samples. Samples that were prepared with vacuum cooking methods on average showed higher total phenol concentration, antiradical activity and total anthocyanins concentration than in control samples cooked under atmospheric conditions. These observations were consistent with reports in the literature on better preservation of bioactive compounds in plant-based products that are cooked under vacuum heat treatment at lower temperatures.
\end{abstract}

Key words: vacuum cooking, vitamin $C$, total phenols, anthocyanins, total carotenes, antiradical activity (2,2-diphenil-1-picrylhydrazyl, DPPH).

\section{INTRODUCTION}

Growing interest in natural food ingredients exhibiting beneficial effects on human health has been an important factor in expanding the studies of less common horticultural plants in recent years (Jordheim et al., 2007; Gruenwald, 2009; Kraujalytè et al., 2012). Plants belonging to the genus $\mathrm{Vi}$ burnum have more than 230 species of shrubs and trees, which are grown mainly as decorative plants. The majority of the genus Viburnum species are endemic. For example, $V$. opulus, the most common species in Europe, occurs in western, central, eastern, and north eastern European regions, and it also grows in northern Asia; V. opulus var. sargentii is native to the Far East in Korea, Northern China, and Japan (Bae et al., 2010; Česonienè et al., 2010; Kraujalytè et al., 2012). There are several common English names of $V$. opulus used in various literature sources: European cranberry bush, snowball tree, guelder rose, squawbush, crampbark (Velioglu et al., 2006; Zayachkivska et al., 2006; Česonienè et al., 2010; Kraujalytè et al., 2012).

The fruits have been used to treat high blood pressure, heart troubles, tuberculosis, shortness of breath, stomach pain, di- gestive troubles, duodenal ulcers and bleedings, kidney and bladder affections, coughs, and colds (Velioglu et al., 2006; Zayachkivska et al., 2006; Bae et al., 2010; Česonienè et al., 2010; Kraujalytė et al., 2012). They also have been used in foods in Europe and Asia, mainly as an ingredient in sauces, jellies, marmalades, and drinks (Velioglu et al., 2006; Rop et al., 2010; Kraujalytė et al., 2012).

$V$. opulus fruits contain high amounts of polyphenolics (Česonienè et al., 2008; Rop et al., 2010; Kraujalytė et al., 2012), ascorbic acid (Česonienė et al., 2008; Česonienė et al., 2010; Rop et al., 2010; Kraujalytė et al., 2012) and L-malic acid (Çam and Hişil, 2007; Kraujalytè et al., 2012). Berry juice was reported to be rich in chlorogenic acid, amounting to $54 \%$ of the total phenolic content (Velioglu et al., 2006; Kraujalytė et al., 2012), which is higher than in some more widely consumed juices and nectars (Çam \& Hişil, 2007; Kraujalytė et al., 2012). The berries have been also reported as a source of flavonoids, including $(+)$-catechin and (-)-epicatechin, quercetin glycosides (Velioglu et al., 2006; Kraujalytė et al., 2012) and proanthocyanidins (Zayachkivska et al., 2006; Kraujalytè et al., 2012). Several anthocyanins have been identified in 
$V$. opulus berries with cyanidin-3-glucoside being the most important representative of this class of compounds (Deineka et al., 2005; Velioglu et al., 2006; Jordheim et al., 2007; Kraujalytė et al., 2012). In addition, they contain carotenoids (Gavrilin et al., 2007; Česonienè et al., 2008; Kraujalytè et al., 2012). The high concentration of phenolics is correlated with strong radical scavenging capacity of $V$. opulus extracts (Çam and Hişil, 2007; Česonienè et al., 2008; Kraujalytė et al., 2012). Plant phenolic compounds are responsible for the organoleptic and health promoting properties of plant products (Kraujalyte et al., 2012). Phenolics, the products of secondary metabolism of plants, are also partly responsible for the colour and the taste of the plant (Duthie et al., 2000; Yao et al., 2004; Karaçelik et al., 2015).

The genus Cucurbita within the family Cucurbitaceae comprises five domesticated species, three of which, C. pepo L., C. maxima Duchesne, and C. moschata Duchesne, represent economically important species cultivated worldwide. The other two domesticated species, $C$. huber and $C$. ficifolia Bouché, have more limited cultivation (Loy, 2011).

Cucurbita moschata is a seasonal crop that has been used traditionally both as human and animal feed. C. moschata is eaten as a vegetable and cultivated for its young shoots, fleshy, edible flowers, and above all, for its fruits. There are numerous culinary uses of this crop, either as a vegetable or as an ingredient in food preparations like pies, soups, stews, breads (Noelia et al., 2011).

The nutritional value of pumpkin fruits is high but varies from one species or cultivar to another. Thus, in the fresh mass of the fruit, the total concentration of carotenoids, a major contributory factor in the high nutritional value of pumpkins, ranges from 2 to $10 \mathrm{mg} \cdot 100 \mathrm{~g}^{-1}$, the content of vitamins $\mathrm{C}$ and $\mathrm{E}$ accounting for $9-10 \mathrm{mg} \cdot 100 \mathrm{~g}^{-1}$ and 1.03-1.06 mg.100 g ${ }^{-1}$, respectively (Assous et al., 2014).

Pumpkin fruit is also a valuable source of other vitamins like K, B1, B2, and B6 as well as minerals, for ecample, K, $\mathrm{F}, \mathrm{Mg}, \mathrm{Fe}$, and $\mathrm{Se}$ (Assous et al., 2014).

The main advantage of using vacuum treatments such as sous vide (SV) and cook-vide (CV) is the absence of oxygen and the use of temperatures below $100{ }^{\circ} \mathrm{C}$, causing less damage to thermolabile compounds, which can improve the final quality. Moreover, lower temperatures promote higher flavor retention of fresh produce, lower production of acrylamide, and higher retention of pigments (IborraBernad et al., 2014).

$\mathrm{CV}$ has been applied in haute cuisine restaurants from the beginning of its development. CV emplys cooking in boiling water at temperatures below $100{ }^{\circ} \mathrm{C}$ by lowering the pressure to reach the vapour pressure of water. The low pressure is maintained during the total cooking time by the continuous function of a pump. There have been few studies on the application of this technique in cooking vegetables and fruit with water. Unlike SV treatments, CV products are cooked in direct contact with water boiling at temperatures lower than $100{ }^{\circ} \mathrm{C}$, by increasing the surface heat transfer coefficient (Iborra-Bernad et al., 2014; Martínez-Hernández et al., 2013).

Vacuum-based cooking treatments have been observed to induce higher microbial reduction (mainly sous vide microwaving) for kailan-hybrid broccoli, compared to conventional cooking (Martínez-Hernández et al., 2013). Moreover, vacuum-based cooking showed better sensory scores (mainly sous vide microwaving) and allowed to reach a moderate softening of the broccoli stem accompanied by a pleasant juiciness with a slight and nice crispness. Cooking treatments, in general, increase the total phenolic concentration and the correlated total antioxidant capacity, especially for microwaved samples. However, increased total phenolic content and antioxidant capacity was not observed among conventional and vacuum-based treatments; in contrast, the total vitamin $\mathrm{C}$ concentration after cooking decreased, showing that vacuum boiling had the best retention, compared to conventional boiling, which showed the lowest concentration (Martínez-Hernández et al., 2013).

The aim of the study was to examine the suitability of heat treatment methods on retention of bioactive compound concentrations in pumpkin-guelder rose sauce.

\section{MATERIALS AND METHODS}

Ingredients. Pumpkin-guelder rose sauce was made from pumpkin puree and gueelder rose juice in concentrations (74.5\% puree and $13.1 \%$ juice) with addition of salt, sugar, and citric acid according to the recepe showed in Table 1. All of the additives before adding to the essential ingredients were finely chopped to homogeneous consistency.

The prepared pumpkin-guelder rose sauces were vacuum cooked under two modes:

1. 0.6 bar pressure, temperature $85 \pm 1^{\circ} \mathrm{C}$ for $15 \mathrm{~min}$;

2. 0.2 bar pressure, temperature $75 \pm 1^{\circ} \mathrm{C}$ for $15 \mathrm{~min}$.

Freshly prepared (no thermal treatment) and sauce samples cooked in atmospheric conditions were also prepared for

Table 1

PUMPKIN-GUELDER ROSE SAUCE RECIPE

\begin{tabular}{l|c}
\hline \multicolumn{1}{c|}{ Ingredients } & Quantity as percentage (\%) \\
\hline Pumpkin puree & 74.5 \\
Guilder rose juice & 13.1 \\
Salt & 0.7 \\
Sugar & 10 \\
Citric acid & 0.5 \\
Dried garlic powder & 0.2 \\
Dried rosemary & 0.2 \\
Pepper & 0.2 \\
Cumin & 0.2 \\
Bay leaves & 0.2 \\
Allspice & 0.2
\end{tabular}


comparison. Samples cooked at atmospheric pressure were boiled in a water bath at temperature $95 \pm 1{ }^{\circ} \mathrm{C}$ for $15 \mathrm{~min}$.

Total carotenoids. Carotenoid concentration was determined by a spectrophotometric method (UV/VIS spectrophotometer, Jenway 6705, Bibby Scientific Ltd., UK), at $440 \mathrm{~nm}$ described by (Kampuse et al., 2012). The concentration of carotenoids $\left(\mathrm{mg} \cdot 100 \mathrm{~g}^{-1}\right.$ ) was calculated by equation (1):

$X=\frac{0.208 * 25 * K E}{36 * a}$

where: coefficients 0.208 and 36 define the relationship between $\mathrm{K}_{2} \mathrm{Cr}_{2} \mathrm{O}_{7}$ and carotenoid concentration;

$K E$ - carotene equivalent from graduation curve;

$a$-sample weight, g (Kampuse et al., 2015).

Vitamine C. Concentration of L-ascorbic acid, the reduced form of ascorbic acid, was determined by the iodine method T-138-15-01:2002 (Seglina, 2007).

Total phenol content. Total phenolic concentration was determined according to the Folin-Ciocalteu method ( $\mathrm{Yu}$ et al., 2003) with modifications:

1. To $0.5 \mathrm{ml}$ of extracted sample, $2.5 \mathrm{~mL} 0.2 \mathrm{~N}$ FolinCiocalteu reagent was added, which was diluted ten times with distilled water;

2. After $5 \mathrm{~min}, 2.0 \mathrm{ml} 7.5 \% \mathrm{NaCO}_{3}$ was added;

3. The resulting solution was mixed and allowed to stand for $30 \mathrm{~min}$ at $18 \pm 1{ }^{\circ} \mathrm{C}$ in the dark;

4. Absorption was read at $760 \mathrm{~nm}$ using a JENWAY 630 Spectrophotometer (Priecina et al., 2014).

Total phenolic concentrationwas expressed as milligrams of gallic acid equvalent per $100 \mathrm{~g}$ per dry weight (GAE $\left.\mathrm{mg} \cdot 100 \mathrm{~g}^{-1}\right)$.

Antiradical scavenging activity. The antiradical scavenging activity of extracts was determined by reaction with stable 2,2-diphenil-1-picrylhydrazyl (DPPH) free radical according to Yu et al. (2003) with modifications:

1. To $0.5 \mathrm{ml}$ of extracted sample, $3.5 \mathrm{ml}$ freshly made DPPH solution (4 mg of DPPH reagent was dissolved in $100 \mathrm{ml}$ pure ethanol) was added;

2. The mixture was shaken and kept in the dark at $18 \pm 1{ }^{\circ} \mathrm{C}$ for $30 \mathrm{~min}$;

3. Absorbance was measured at $517 \mathrm{~nm}$ using a JENWAY 630 Spectrophotometer (Priecina et al., 2014).

The antiradical scavenging activity was expressed as micromolar equvalents of Trolox per $100 \mathrm{~g}$ dry weight $(\mathrm{mM}$ $\mathrm{TE} \cdot 100 \mathrm{~g}^{-1}$ ).

Total anthocyanins. $20.00 \mathrm{~g}$ samples were taken in two replicates, to which $40 \mathrm{ml}$ of previously prepared ethyl alco- hol $+1.5 \mathrm{HCl}$ solution was added. The mixture was ground in a blender for $1 \mathrm{~min}$, filtered through filter paper, and precipitated three times by washing with $3 * 10 \mathrm{ml}$ etanol and $1.5 \mathrm{ml} \mathrm{HCl}$ solution (total $30 \mathrm{ml}$ ). The resultinng extract was further analyzed with a Jenway 6705 spectrophotometer at wavelenght $535 \mathrm{~nm}$. The samples were diluted with ethyl alcohol $+1.5 \mathrm{M} \mathrm{HCl}$ solution to achieve an absorption coefficient within the range of 0.6 to 0.8 . Anthocyanins concentration of the sample was calculated using equation (2) (Moor et al., 2005):

$C=\frac{A * v * 1000}{980 * m}$

where: A - absorbtion coefficient

$\mathrm{v}$ - extract total volume (90)

d - dillution

m - sample weight (g) (Moor et al., 2005).

For analysis of total carotenoids, anthocyanins, phenols and antiradical scavenging activity, two product replicates and two chemical replicates were used, except for vitamin C, where one chemical replicate was used. Mean concentrations were calculated.

\section{RESULTS}

Several pumpkin sauces (experimental samples) were prepared using different cooking methods and two guelder rose hybrids and one variety and the properties of the sauces were compared. Freshly mixed samples, and those cooked under atmospheric conditions and in vacuum under two different modes were compared. All of concentrations were calculated per dry matter, as the most effecive comparison method for samples with different moisture content.

The highest concentration of total carotines was found in control samples (cooked under atmospheric pressure in a water bath), which reached up to $8.78 \mathrm{mg} \cdot 100 \mathrm{~g}^{-1}$ dry weight; fresh sauce samples that were not cooked had the smallest total carotine content (Table 2). The highest guelder rose of carotines was observed in S3 samples prepared under vacuum (6.61 mg.100 g $\mathrm{g}^{-1}$ dry weight), while the sample preparation under vacuum cooking did not significantly affect the total carotines concentration, compared to the control samples.

Statistically no significant difference was found between the total carotene concentration of the hybrids/variety, but was observed between the type of treatment $(p<0.05)$.

In contrast to the total carotene concentration, where cooking under vacuum had a positive effect in product, the concentration of ascorbic acid (Fig. 1) was significantly lower in all samples after heat treatment. There was a significant difference in the concentration of vitamin $\mathrm{C}$ among the sauce samples $(p<0.05)$. The $\mathrm{S} 1$ samples with hybrid $2-30-\mathrm{K}$ fruits had the highest ascorbic concentration, but af- 
CONCENTRATION OF TOTAL CAROTENES, TOTAL PHENOLS, ANTHOCYANIN AND ANTIRADICAL ACTIVITY IN EXPERIMENTAL SAMPLES PER DRY MATTER

\begin{tabular}{|c|c|c|c|c|c|}
\hline Type of treatment & Sample & $\begin{array}{l}\text { Total carotenes } \\
\left(\mathrm{mg} \cdot 100 \mathrm{~g} \mathrm{~g}^{-1}\right)\end{array}$ & $\begin{array}{c}\text { Total phenols } \\
\left(\mathrm{GAE} \mathrm{mg} \cdot 100 \mathrm{~g}^{-1}\right)\end{array}$ & $\begin{array}{l}\text { Anthocyanins } \\
\left(\mathrm{mg} \cdot 100 \mathrm{~g}^{-1}\right)\end{array}$ & $\begin{array}{l}\text { Antiradical activity } \\
\left(\mathrm{mM} \text { TE } \mathrm{mg} \cdot 100 \mathrm{~g}^{-1}\right)\end{array}$ \\
\hline \multirow[t]{3}{*}{ Fresh } & $\mathrm{S} 1$ & $5.24 \pm 0.13 c$ & $1385.11 \pm 32.39 \mathrm{a}$ & $28.15 \pm 2.66 c$ & $203.23 \pm 6.14 a$ \\
\hline & $\mathrm{S} 2$ & $6.10 \pm 0.03 c$ & $889.70 \pm 26.49 a$ & $22.76 \pm 0.56 c$ & $193.08 \pm 28.39 \mathrm{a}$ \\
\hline & $\mathrm{S} 3$ & $6.61 \pm 0.50 \mathrm{c}$ & $864.70 \pm 27.01 \mathrm{a}$ & $25.64 \pm 0.71 \mathrm{c}$ & $246.97 \pm 6.61 \mathrm{a}$ \\
\hline \multirow[t]{3}{*}{ Control } & $\mathrm{S} 1$ & $8.78 \pm 0.12 \mathrm{a}$ & $800.74 \pm 36.85 b$ & $17.24 \pm 0.71 \mathrm{~d}$ & $167.73 \pm 13.95 b$ \\
\hline & $\mathrm{S} 2$ & $7.80 \pm 0.01 \mathrm{a}$ & $631.92 \pm 13.87 b$ & $13.12 \pm 1.33 \mathrm{~d}$ & $135.04 \pm 13.74 b$ \\
\hline & $\mathrm{S} 3$ & $8.41 \pm 0.01 \mathrm{a}$ & $646.99 \pm 12.97 b$ & $13.85 \pm 0.13 \mathrm{~d}$ & $167.21 \pm 29.48 b$ \\
\hline \multirow[t]{3}{*}{0.6 bar pressure } & $\mathrm{S} 1$ & $7.74 \pm 0.25 a, b$ & $985.377 \pm 16.65 \mathrm{c}$ & $21.38 \pm 1.16 \mathrm{e}$ & $193.26 \pm 0.25 \mathrm{c}$ \\
\hline & $\mathrm{S} 2$ & $7.75 \pm 0.08 \mathrm{a}, \mathrm{b}$ & $983.119 \pm 45.20 \mathrm{c}$ & $15.57 \pm 0.11 \mathrm{e}$ & $194.18 \pm 7.38 \mathrm{c}$ \\
\hline & $\mathrm{S} 3$ & $8.10 \pm 0.07 \mathrm{a}, \mathrm{b}$ & $805.088 \pm 31.16 \mathrm{c}$ & $14.11 \pm 0.12 \mathrm{e}$ & $187.04 \pm 19.01 \mathrm{c}$ \\
\hline \multirow[t]{3}{*}{02 bar pressure } & $\mathrm{S} 1$ & $7.54 \pm 0.31 b$ & $1080.96 \pm 41.12 \mathrm{c}$ & $20.07 \pm 0.57 \mathrm{e}$ & $218.36 \pm 6.02 c$ \\
\hline & $\mathrm{S} 2$ & $7.77 \pm 0.99 b$ & $836.14 \pm 21.49 c$ & $16.31 \pm 0.09 \mathrm{e}$ & $180.24 \pm 18.70 c$ \\
\hline & S3 & $7.95 \pm 0.75 b$ & $778.81 \pm 74.75 c$ & $17.04 \pm 0.06 \mathrm{e}$ & $152.52 \pm 4.57 \mathrm{c}$ \\
\hline
\end{tabular}

S1 sauces made from guelder rose fruit hybrid $230 \mathrm{~K}$; S2 sauces made from guelder rose fruit hybrid $245 \mathrm{~K}$; S3 sauces made from guelder rose fruit variety Krasnaya Grozdj. The same added letter to numbers show that there are no significant differences between the evaluated samples $(p>0.05)$ depending on the type of treatment

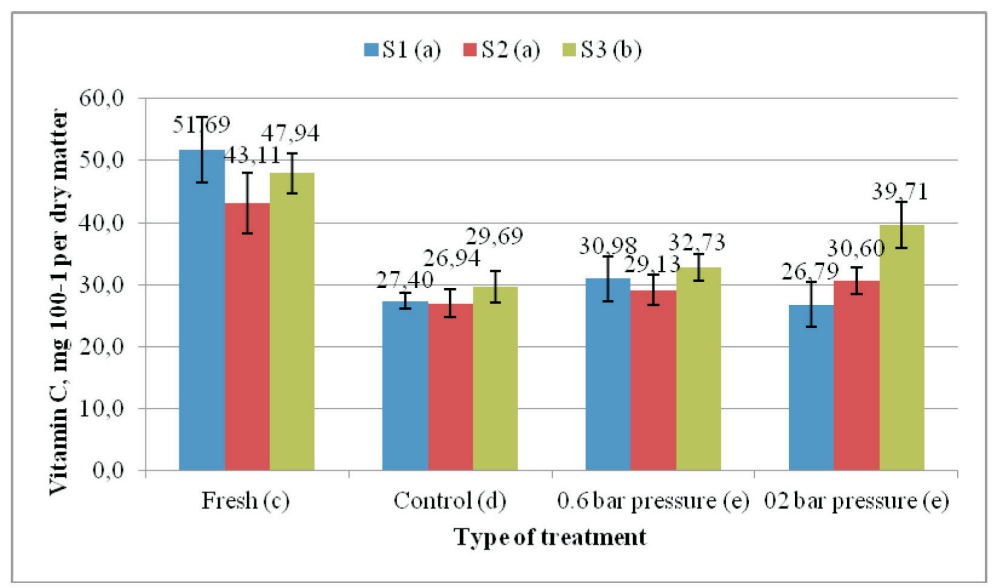

Fig. 1. The concentration of vitamin $\mathrm{C}$ in different pumpkin--guilder rose sauce samples. S1 sauces made from guelder rose fruit hybrid $230 \mathrm{~K}$; S2 sauces made from guelder rose fruit hybrid $245 \mathrm{~K}$; S3 sauces made from guelder rose fruit variety Krasnaya Grozdj. Type of treatment and sample, marked with the same letter shows that there are no significant differences between the evaluated samples $(p>0.05)$ ter the heat treatment the concentration was preserved better in the S3 samples with variety 'Krasnaya Grozdj' fruits (Fig. 1). Also a significant difference was found between fresh and heat-treated samples, and between control samples and vacuum cooked samples $(p<0.05)$, but there were no significant differences between the vacuum cooking modes. $(p>0.05)$

Table 2 shows total phenol concentration in sauce samples. As in the concetration of the other compounds, there was difference in total phenol concentration between treatments, with the lowest in the control samples, and somewhat less difference in vacuum cooked samples.

There was also a significant difference between the treatment methods on the ascorbic acid concentration $(p<0.05)$. There was a significant differance in concentration of total phenols between fresh samples and samples treated under heat, but not between vacuum cooking modes. Sauces prepared under vacuum had higher total phenol concentration.

Treatment S2 prepared at 0.6 bar had a higher total phenol content (889.704 GAE mg.100 g ${ }^{-1}$ dry matter) than in the fresh sample (983.119 GAE mg.100 $\mathrm{g}^{-1}$ in dry matter), while in other samples the total phenol concentration after heat treatment was lower (Table 2). There was a significant difference between the total phenolic concentration depending on the hybrid/variety of guelder rose were used; S1 sauces had the highest total phenol concentration and variety 'Krasnaya Grozdj' sauce S3 had the lowest $(p<0.05)$.

The largest antiradical activity changes (Table 2) were found in control samples, and cooking under vacuum had less affect, although there was no significant difference between the two vacuum processing modes $(p<0.05)$. The biggest change occurred in samples $\mathrm{S} 3$ : fresh sauce sample antiradical activity was $246.96 \mathrm{mMTE} \cdot 100 \mathrm{~g}^{-1}$ dry matter, while samples prepared at 0.2 bar had only 152.51 mMTE. $100 \mathrm{~g}^{-1}$ dry matter. In the same mode, in sample S1 the antiradical activity was higher $\left(218.36 \mathrm{mMTE} \cdot 100 \mathrm{~g}^{-1}\right.$ dry matter), but no signifficant difference between these samples was found $(p>0.05)$.

Similarly to the changes of vitamin C (Fig. 1), a significant difference of anthocyanin concentration (Table 1) was ob- 
served depending on the type of the heat treatment $(p<$ $0.05)$. In samples prepared under vacuum a higher content of anthocyanins was found than in the control samples, but less than in fresh sauce samples, while no significant difference between the vacuum processing modes was found.

A significant difference in the average anthocyanin concentration was between sauce samples prepared with different hybrids/variety of guelder rose fruits. The highest concentration of anthocyanins was found in hybrid 2-30-K fresh sample S1 $2\left(8.15 \cdot 100 \mathrm{~g}^{-1}\right.$ dry matter), also processing (0.6 bar - $21.37 \mathrm{mg} \cdot 100 \mathrm{~g}^{-1}$ dry matter) (Table 1).

\section{DISCUSION}

The results of the study on higher total carotine content in sauce samples cooked in atmospheric conditions than in raw sauce samples are not supported by the literature, and explanation of the changes that occurred in the chemical composition of sauces is lacking.

Product processing under vacuum compared to conventional heat treatment is much less aggressive on plant-based product cells containing bioactive compounds, including anthocyanins, as lower processing temperatures are used (Iborra-Bernad et al., 2015; Martínez-Hernández et al., 2013), while processing at temperature above $70{ }^{\circ} \mathrm{C}$ is able to significantly reduce both vitamin $\mathrm{C}$ and anthocyanin and other bioactive compound concentration of the products (Galoburda et al., 2012).

In a previous study (Martínez-Hernández et al., 2013) on innovative cooking techniques for improving the overall quality of Kailan-Hybrid broccoli, it was also concluded that vacuum-based cooking treatments generally showed better microbial, physical and sensory quality, preserving, or even improving, antioxidant concentration compared to conventional methods (Martínez-Hernández et al., 2013).

\section{CONCLUSIONS}

It can be concluded that there was no significant diference in the chemical composition of the sauces depending on the vacuum treatment regime, but this type of treatment provides better preservation of concentrations of vitamin $\mathrm{C}$, total phenols, anthocyanins and antiradical activity of the product compared with product boiling at atmospheric pressure.

The best experimental results were obtained by vacuum cooking at 0.2 bar pressure of sauces prepared with variety 'Krasnaya Grozdj'. This sample had the highest vitamin C concentration $\left(39.71 \mathrm{mg} \cdot 100 \mathrm{~g}^{-1}\right.$ dry matter).

\section{ACKNOWLEDGEMENTS}

Studies have been carried out with the National Research Programme "Sustainable Agricultural Resources of High Quality and Healthy Food Production in Latvian
(AgroBioRes) (2014-2017)”, Project No. 4 “Local agricultural resource, sustainable use of high-quality and healthy food product development (FOOD) framework".

\section{REFERENCES}

Assous, M. T. M., Soheir Saad, E. M., Dyab, A. S. (2014). Enhancement of quality attributes of canned pumpkin and pineapple. Ann. Agr. Sci., 59 (1), 9-15.

Bae, K. E, Chong, H. S., Kim, D. S., Choi, Y. W., Kim, Y. S, Kim Y. K. (2010). Compounds from Viburnum sargentii Koehne and evaluation of their cytoxic effects on human cancer cell lines. Molecules, 15 (7), 4599-4609.

Çam, M., Hisil, Y. (2007). Comparison of chemical characteristics of fresh and pasterised juice of gilaburu (Viburnum opulus L.). Acta Alimentaria, 36 (3), 381-385.

Česonienė, L., Daubaras, R., Venclovienė, J., Viškelis, P. (2010). Biochemical and agro-biological diversity of Viburnum opulus genotypes. Central Eur. J. Biol., 5 (6), 864-871.

Česonienė, L., Daubaras, R., Viskelis, P. (2008). Evaluation of productivity and biochemical components in fruit of different Viburnum accessions. Biologia, 54 (2), 93-96.

Deineka, V. I., Sorokopudov, V. N., Deineka, L. A., Kol'tsov, S. V (2005). Anthocyans from fruit of some plants of the Caprofoliaceae familiy. Chem. Nat. Comp., 41 (2), 162-164.

Duthie, G. G., Duthie, S., Kyle, J. A. M. (2000). Plant polyphenols in cancer and heart disease implications as nutritional antioxidants. Nutr. Res. Rev., 13 (1), 79-106.

Galoburda, R., Augšpole, I., Berņa, I., Dabiṇa--Bicka, I., Kampuse, S., Kampuss, K., Krūma, Z., Kunkulberga, D., Mūrniece, I., Ozoliņa, V., Rakcejeva, T., Rūse, K., Šnē, E. (2012). Vitamīni. No: Biologiski aktīvās vielas pārtikas produktos [Vitamins. In: Biologically active substances in foodstuffs]. LLU, Jelgava, 15.-91. 1pp. (in Latvian).

Gruenwald, J. (2009). Novel botanical ingredients for beverages. Clin. Dermatol., 27, 210-216.

Iborra-Bernad, C., García-Segovia, P., Martínez--Monzü, J. (2015). Physico-chemical and structural characteristics of vegetables cooked under souse-vide, cook-vide and conventional boiling. J. Food Sci., 80 (8), E1725-E1734.

Iborra-Bernad, C., Tárrega, A., García-Segovia, P. (2014). Comparison of vacuum treatments and traditional cooking using instrumental and sensory analysis. Food Anal. Meth., 7, 400-408.

Jordheim, M., Giske, N. H., Andersen, Ø. M. (2007), Anthocyanins in Caprofoliaceae. Biochem, Syst. Ecol., 35 (3), 153-159.

Kampuse, S., Berna, E., Muizniece-Brasava, S., Dukalska, L., Murniece,I., Sabovics, M., Kruma, Z., Ruse, K., Sarvi, S., Kampuss, K. (2012). Influence of active packaging on the quality of pumpkin - rowanberry marmalade candies. World Acad. Sci. Eng. Technol., 6 (7), 1341-1349.

Kampuse, S., Ozola, L., Straumite, E., Galoburda, R. (2015). Quality parameters of wheat bread enrished with pumpkin (Cucurbita moschata) by-products. Acta Univ. Cibiniensis, Series E: Food Technol., 19 (2), 3-14.

Karaçelik, A. A., Küçük, M., Ískefiyeli, Z., Aydemir, S., De Smet, S., Miserez, B., Sandra, P. (2015). Antioxidant components of Viburnum opulus L. Determined by on-line HPLC-UV-ABTS radical scavenging and LC-UV-ESI-MS methods. Food Chem., 175,106-114.

Kraujalytė, V., Leitner, E., Venskutonis, P.bR. (2012). Chemical and sensory characterisation of aroma of Viburnum opulus fruits by solid phase microextraction-gas chromatography-olfactometry. Food Chem., 132 (2), $717-723$. 
Loy, J. B. (2011). Genetics, Genomics and Breeding of Cucurbits. Science Publishers 2011. Available from: http://www.crcnetbase.com (accessed 2 October 2016) DOI: 10.1201/b11436-5.

Martínez-Hernández, G. B., Artés-Hernández, F., Colares-Souza, F., Gómez, P. A., García-Gómez, P., Artés F. (2013). Innovative cooking techniques for improving the overall quality of Kailan-Hybrid broccoli. Food Bioproc. Technol., 6 (8), 2135-2149.

Moor, U., Karp, K., Poldma, P., Pae, A. (2005). Cultural systems affect content of anthocyanins and vitamin $\mathrm{C}$ in strawberry fruits. Eur. J. Horticult. Sci., 70 (4), 195-201.

Noelia, J.-V., Roberto, M.-J. M., Jesús, de Z.-M. J., Alberto, G.-I. J. (2011). Physicochemical, technological properties and health-benefits of Cucurbita moschata Duchense vs.Cehualca: A Review. Food Res. Int., 44, 2587-2593.

Prieciņa, L., Kārkliņa, D. (2014). Natural antioxidant changes in fresh and dried spices and vegetables. Int. J. Biol. Biomol. Agr. Food Biotechn. Eng., $8(5), 492-496$.

Received 13 November 2016

Accepted in the final form 23 November 2017
Rop, O., Reznicek, V., Valsikova, M., Jurikova, T., Mlcek, J., Kramarova, D. (2010). Antioxidant properties of European cranberrybush fruit (Viburnum opulus var. edule). Molecules, 15 (6), 4467-4477.

Segliņa, D. (2007). Materiāli un metodes: Smiltsērkšḳu aug̣̣i un to pārstrādes produkti [Sea Buckthorn Fruits and Their Processing Products]. Doctoral dissertation, Latvia University of Agriculture, Jelgava, Latvia (in Latvian).

Velioglu, Y. S., Ekici, L., Poyrazoğlu, E. S. (2006). Phenolic composition of European cranberry bush (Viburnum opulus L.) berries and astringency removal of its commercial juice. Int. J. Food Sci. Technol., 41 (9), 1011-1015.

Yao, L. H., Jing, Y. M., Shi, J., Tomas-Barberan, F.A., Datta, N., Singanuson, R., Chen, S. S. (2004). Flavonoids in food and their health benefits. Plant Foods Human Nutr., 59, 113-122.

Yu, L., Haley, S., Perret, J., Harris, M., Wilson, J., Haley, S. (2003). Antioxidant properties of bran extracts from Akron wheat grown at different locations. J. Agricult. Food Chem., 51 (6), 1566-1570.

Zayachkivska, O. S., Gzhegotsky, M. R., Terletska, O. I., Lutsyk, D. A., Yaschenko, A. M., Dzhura, O. R. (2006). Influence of Viburnum opulus proanthocuanidins on stress-induced gastrointestinal mucosal damage. $J$. Physiol. Pharmacol., 57 (5), 155-167.

\section{TERMISKĀS APSTRĀDES METOŽU IETEKME UZ K়IRBJU-IRBEṆU (VIBURNUM OPULUS) MĒRČU UZTURVIELU SASTĀVU}

Pētījuma mērkis ir izpētīt termiskās apstrādes metožu piemērotību ḳirbju-irbeṇu mērču bioaktīvo savienojumu saglabāšanās spējai. Šim nolūkam izvēlēti augḷu hibrīdi 2-30-K; 2-45-K un irbeṇu šḳirne 'Krasnaja Grozdj'. Izmantojot šo ogu sulas, tika izveidoti kirbju-irbeṇu mērču paraugi, kur ķirbju biezeņa un irbeņu ogu sulas attiecībā 74,5:13,1 un veikta to termiskā apstrāde atmosfēras spiedienā (tradicionālā vārišana) un vakuumā atškirīgos režīmos 0,6 bar $85^{\circ} \mathrm{C}$ un 0,2 bar $75^{\circ} \mathrm{C}$ temperatūrā, visi paraugi salīdzināti ar termiski neapstrādātiem kirbju-irbeņu mērču paraugiem. Veicot k̦irbju-irben,u mērču ķīmisko izvērtējumu, tika novērota labāka C vitamīna saglabāšanās 0,2 bar spiedienā vārītā irbeņu šķirnes 'Krasnaja Grozdj' mērču paraugā salīdzinājumā ar svaigā paraugā esošā C vitamīna daudzumu, pārrēkinot uz sausnu. Vakuuma vārīšanas katlā sagatavotie mērču paraugi sausnā vidēji uzrādīja lielāku kopējo fenolu, antiradikālās aktivitātes un kopējo antociānu saturu nekā kontroles paraugi, kas vārīti atmosfēras spiedienā. Šādi novērojumi sakrīt ar literatūrā sniegto informāciju par labāku bioaktīvo savienojumu saglabāšanos augu valsts produktos, kas sagatavoti vakuumā pie zemākām termiskās apstrādes temperatūrām. 